\title{
Synthesis and reactivity of di(silylamido)cyclopentadienyl titanium and zirconium complexes
}

\author{
Jesús Cano, María Sudupe, Pascual Royo * \\ Departamento de Química Inorgánica, Facultad de Química, Universidad de Alcalá, Campus Universitario, E-28871 Alcalá de Henares, Spain
}

Received 11 April 2007; received in revised form 31 May 2007; accepted 7 June 2007

Available online 3 July 2007

Dedicated to Prof. Dr. Gerhard Erker on the occasion of his 60th birthday.

\begin{abstract}
We present in this account the synthesis and recent developments of a new class of group 4 metal complexes with the tridentate di(silylamido)cyclopentadienyl ligand. These doubly silyl-bridged group 4 metal amido chelates are receiving increasing interest as they are efficient catalysts for ethene polymerization when activated with MAO despite generating 14-electron $\mathrm{d}^{0}$ cationic species free of the alkyl group required for the first insertion reaction in the polymerization process.
\end{abstract}

(C) 2007 Elsevier B.V. All rights reserved.

Keywords: Silylamido; Cyclopentadienyl; Titanium; Zirconium

\section{Introduction}

The disadvantage of using metallocene complexes to produce polyolefins is the limited temperature stability of the catalyst and the tendency to produce lower molecular weight materials under convenient commercial operating conditions. Many efforts have been made in commercial and academic labs to develop other coordination compounds in which the selectivity and/or productivity is improved. Development of a new catalytic system based on $\eta^{5}$-cyclopentadienyl-silyl- $\eta^{1}$-amido ligand ("CGC", constrained geometry catalysts) has headed this field [16]. When compared to bis-cyclopentadienyl compounds (metallocenes), CGC are stable up to reaction temperatures of $160{ }^{\circ} \mathrm{C}$, have increased stability toward MAO, and give generally higher molecular weight polymers. Ligand design has been tailored with respect to particular catalytic activities or polymer properties.

\footnotetext{
* Corresponding author. Tel.: +34 91 8854765; fax: +34 918854683.

E-mail address: Pascual.Royo@uah.es (P. Royo).
}

Group 4 metallocene complexes after alkyl abstraction by a Lewis acid (MAO, $\left.\mathrm{B}\left(\mathrm{C}_{6} \mathrm{~F}_{5}\right)_{3},\left[\mathrm{CPh}_{3}\right]\left[\mathrm{B}\left(\mathrm{C}_{6} \mathrm{~F}_{5}\right)_{4}\right]\right)$ generate 14-electron $\mathrm{d}^{0}\left[\mathrm{MCp}_{2} \mathrm{R}\right]^{+}$species, assumed to be the active species in the polymerization process $[7,8]$, whereas silyl- $\eta$-amidocyclopentadienyl complexes provide the electronically more unsaturated 12-electron $\mathrm{d}^{0}\left[\mathrm{M}\left(\eta^{5}-\mathrm{C}_{5} \mathrm{R}_{4}\right.\right.$ Si- $\left.\left.\eta^{1}-\mathrm{NR}\right) \mathrm{R}\right]^{+}$cations $[9,10]$ (Fig. 1 ).

Subsequently, a related singly bridged silyl- $\eta$-amido zirconium dicyclopentadienyl compound [11] was also found to be an efficient catalyst for olefin polymerization when treated with aluminium activators. Similar observations have been made more recently for $\mathrm{Co}(\mathrm{I})-\mathrm{R}$ alkyl compounds when treated with $\mathrm{B}\left(\mathrm{C}_{6} \mathrm{~F}_{5}\right)_{3}[12,13]$ or MAO [14] and for $\mathrm{Co}(\mathrm{I})-\mathrm{Cl}$ compounds, without alkyl groups, which show ethene polymerization activity when treated with $\mathrm{LiB}\left(\mathrm{C}_{6} \mathrm{~F}_{5}\right)_{4}[15,16]$ (Fig. 2).

In this paper, we present the synthesis of a new class of group 4 metal complex with a tridentate cyclopentadienyl ligand tethered by two silyl- $\eta$-amido groups. These doubly silyl-bridged group 4 metal amido chelates [17-19] activated with MAO are efficient catalysts for ethene polymerization despite generating alkyl-free 14 -electron $\mathrm{d}^{0}$ cationic species. 

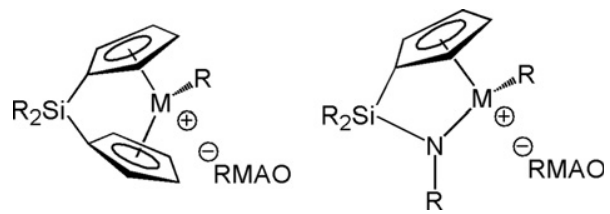

Fig. 1. Alkyl-containing cations.
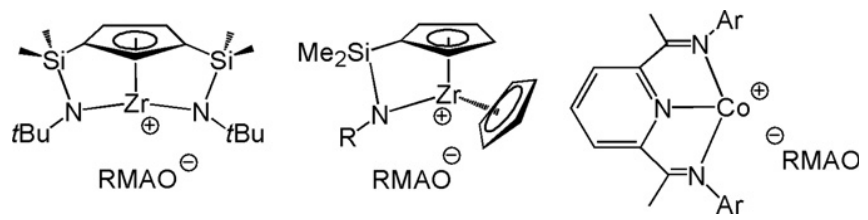

Fig. 2. Alkyl-free cations.

We also report recent developments on the reactivity of their silylamido bridges, the insertion reactions into their metal-alkyl bonds and the generation and reactivity of their cationic derivatives assumed to be the active species in the polymerization process, affording some evidence of a reaction pathway producing the deactivation of the cationic species.

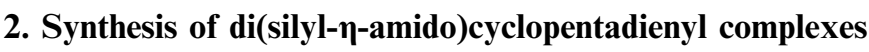

The ${ }^{1} \mathrm{H}$ NMR spectrum of the cyclopentadiene compound $\mathrm{C}_{5} \mathrm{H}_{4}\left(\mathrm{SiMe}_{2} \mathrm{NH} t \mathrm{Bu}\right)_{2}$ (1) recorded at $20^{\circ} \mathrm{C}$ indicated a mixture of isomers $\mathbf{a}, \mathbf{b}, \mathbf{c}$ and $\mathbf{d}$ in a molar ratio of 8:4:1.3:1 (Fig. 3). All of these isomers interconvert, probably through successive 1,2-shifts of the silyl groups [20], and increasing temperatures increase the $\mathbf{a} / \mathbf{b}$ ratio to $4: 1$ at $50{ }^{\circ} \mathrm{C}, 8: 1$ at $70{ }^{\circ} \mathrm{C}$ and more than $10: 1$ at temperatures higher than $80^{\circ} \mathrm{C}$.

We prepared doubly silylamido-bridged group 4 metal complexes by deprotonation with $\mathrm{MBz}_{4}$ or $\mathrm{M}\left(\mathrm{NMe}_{2}\right)_{4}$ $(\mathrm{M}=\mathrm{Ti}, \mathrm{Zr})$ of the tribasic di(aminosilyl)cyclopentadiene 1 under different thermal conditions [17,18], to generate the metal-coordinated cyclopentadienyl ligand (Scheme 1).

When a toluene solution of $\mathbf{1}$ was treated at room temperature with 1 equiv. of $\mathrm{Zr}\left(\mathrm{NMe}_{2}\right)_{4}$, immediate deprotonation of the most acidic cyclopentadiene proton occurred to give the monocyclopentadienyl compound $\mathbf{3}$

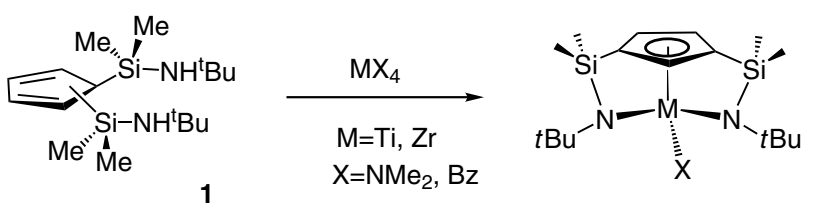

Scheme 1.

after $1 \mathrm{~h}(100 \%$ NMR yield $)$. Heating at $50{ }^{\circ} \mathrm{C}$ was required when $\operatorname{Ti}\left(\mathrm{NMe}_{2}\right)_{4}$ was used to complete the formation of the titanium derivative 2 (Scheme 2). The ${ }^{13} \mathrm{C}$ NMR spectra of 2 and $3\left(\mathrm{C}_{6} \mathrm{D}_{6}\right)$ are consistent with the presence of uncoordinated $\mathrm{SiMe}_{2}-\mathrm{NH} t \mathrm{Bu}$ groups.

Similar heating of toluene solutions of $\mathbf{2}$ and $\mathbf{3}$ to reflux or $65^{\circ} \mathrm{C}$, respectively, gave complete transformation into 4 and 5. The deprotonation of only one of the $\mathrm{Si}-\mathrm{Me}_{2} \mathrm{NH} t \mathrm{Bu}$ substituents with elimination of amine $\mathrm{NHMe}_{2}$ occurred in a selective way to give pure $\mathrm{Ti}(\mathbf{4})$ and $\mathrm{Zr}(\mathbf{5})$. Both can be easily distinguished by the different $\Delta \delta$ values [21-23] observed in the ${ }^{13} \mathrm{C}$ NMR spectra, which are smaller for uncoordinated $\mathrm{NH} t \mathrm{Bu}$ than for bridging $\mathrm{N} t \mathrm{Bu}$ groups.

Temperatures higher than reflux in toluene were required to achieve similar deprotonation of the amido complexes 4 and 5 . The reaction was monitored by ${ }^{1} \mathrm{H}$ NMR spectroscopy with a $\mathrm{C}_{6} \mathrm{D}_{6}$ solution of 5 in a Teflon-valved NMR tube. Complete deprotonation was observed after $12 \mathrm{~h}$ of heating at $120^{\circ} \mathrm{C}$, giving the bis(silylamido) compound 7 as the only reaction product. However, this reaction was reversible when the solution was cooled to room temperature, and 7 could not be isolated as it reacted in solution with the eliminated amine $\mathrm{NHMe}_{2}$ to give the starting product $\mathbf{5}$ quantitatively. Similar deprotonation of the titanium compound $\mathbf{4}$ required heating at temperatures higher than $160^{\circ} \mathrm{C}$ to afford the bis(silylamido)titanium derivative $\mathbf{6}$. The ${ }^{13} \mathrm{C}$ NMR spectra of $\mathbf{6}$ and $7\left(\mathrm{C}_{6} \mathrm{D}_{6}\right)$ are consistent with the presence of bridging $\mathrm{N} t \mathrm{Bu}$ groups.

Further deprotonation of the benzyl compounds $\mathrm{M}\left(\mathrm{CH}_{2} \mathrm{Ph}\right)_{4}(\mathrm{M}=\mathrm{Ti}, \mathrm{Zr})$ occurred very easily at room temperature to give the mono- and di(silylamido) benzyl complexes, preventing the isolation of the tribenzyltitanium and zirconium derivatives. The deprotonation with irreversible toluene elimination by the tetrabenzyl compounds $\mathrm{M}\left(\mathrm{CH}_{2} \mathrm{Ph}\right)_{4}$ is much easier than the reversible elimination of amine by the amido derivatives $\mathrm{M}\left(\mathrm{NMe}_{2}\right)_{4}$, and
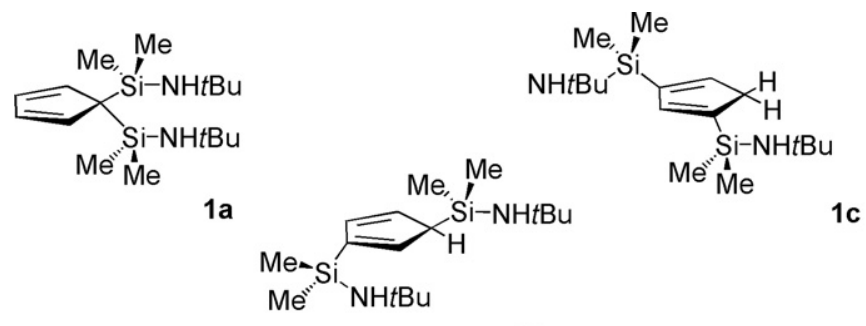

1b

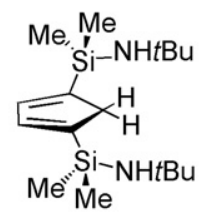

1d

Fig. 3. Isomers of $\mathrm{C}_{5} \mathrm{H}_{4}\left(\mathrm{SiMe}_{2} \mathrm{NHtBu}\right)_{2}$ observed by NMR spectroscopy. 

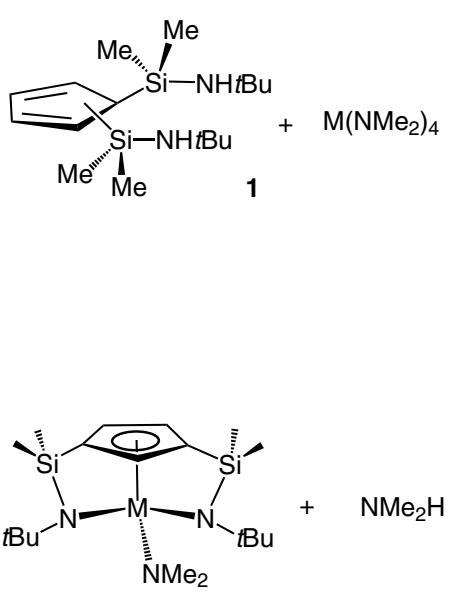

Ti 6, Zr 7

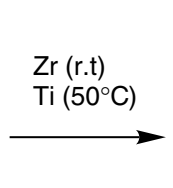

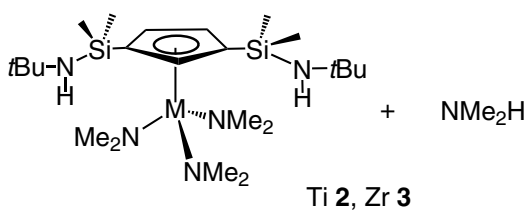

$\operatorname{Zr}\left(65^{\circ} \mathrm{C}\right)$

$\mathrm{Ti}\left(110^{\circ} \mathrm{C}\right)$

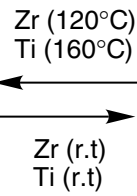

Scheme 2. the zirconium compounds are more easily deprotonated than the more crowded titanium analogues (Scheme 3).

Heating a toluene solution containing an equimolar mixture of 1 and $\mathrm{Ti}\left(\mathrm{CH}_{2} \mathrm{Ph}\right)_{4}$ for $5 \mathrm{~h}$ below $70^{\circ} \mathrm{C}$ gave the dibenzyl[di(silylamido)cyclopentadienyl] titanium compound 8. Temperatures higher than $70{ }^{\circ} \mathrm{C}$ could not be used, since further deprotonation would then give small amounts of 10. Nevertheless, the third deprotonation could not be avoided when the $\mathrm{Zr}$ derivative was used. Compound 9 was characterized only by NMR spectroscopy because the products could not be separated. Complete deprotonation of the uncoordinated $\mathrm{SiMe}_{2}-\mathrm{NH} t \mathrm{Bu}$ groups in the dibenzyl complexes 8 and $\mathbf{9}$ required heating their toluene solutions under reflux or $70^{\circ} \mathrm{C}$, respectively, to give the di(silylamido) compounds $\mathbf{1 0}$ and 11. These compounds can be easily distinguished by the different $\Delta \delta$ values [2123] observed in the ${ }^{13} \mathrm{C} \mathrm{NMR}$ spectra, which are lower for uncoordinated $\mathrm{NH} t \mathrm{Bu}$ than for bridging $\mathrm{N} t \mathrm{Bu}$ groups.
Pure 7 was obtained at a preparative level when the same thermal treatment of $\mathbf{5}$ was carried out in a Teflonvalved Schlenk tube after addition of 1 equiv. of the monobenzylzirconium compound 11, which reacts with amine in an irreversible reaction to give 7 with elimination of toluene (see Scheme 4).

Considering that in all reactions the first deprotonation involves the most acidic cyclopentadiene proton, we decided to react 1 with 1 equiv. of base in order to obtain the monolithium salt $\mathrm{LiC}_{5} \mathrm{H}_{3}\left[\mathrm{SiMe}_{2}(\mathrm{NH} t \mathrm{Bu})\right]_{2}$ (12). Compound 12 reacts with the corresponding tetrachlorides $\mathrm{MCl}_{4}$ in a straightforward way to give the more versatile chloro bis(dimethylsilylamino) monocyclopentadienyl titanium and zirconium complexes $\left[\mathrm{M}\left\{\eta^{5}-\mathrm{C}_{5} \mathrm{H}_{3}\left[\mathrm{SiMe}_{2}(\mathrm{NH} t\right.\right.\right.$ $\left.\mathrm{Bu})_{2}\right\} \mathrm{Cl}_{3}$ ] $(\mathrm{M}=\mathrm{Ti}, 13 ; \mathrm{Zr}, 14)$ [24]. The total alkylation of 13 and 14 with $\mathrm{MeMgCl}$, followed by toluene reflux, afforded compounds $\mathbf{1 5}$ and $\mathbf{1 6}$ by methane elimination (Scheme 5).
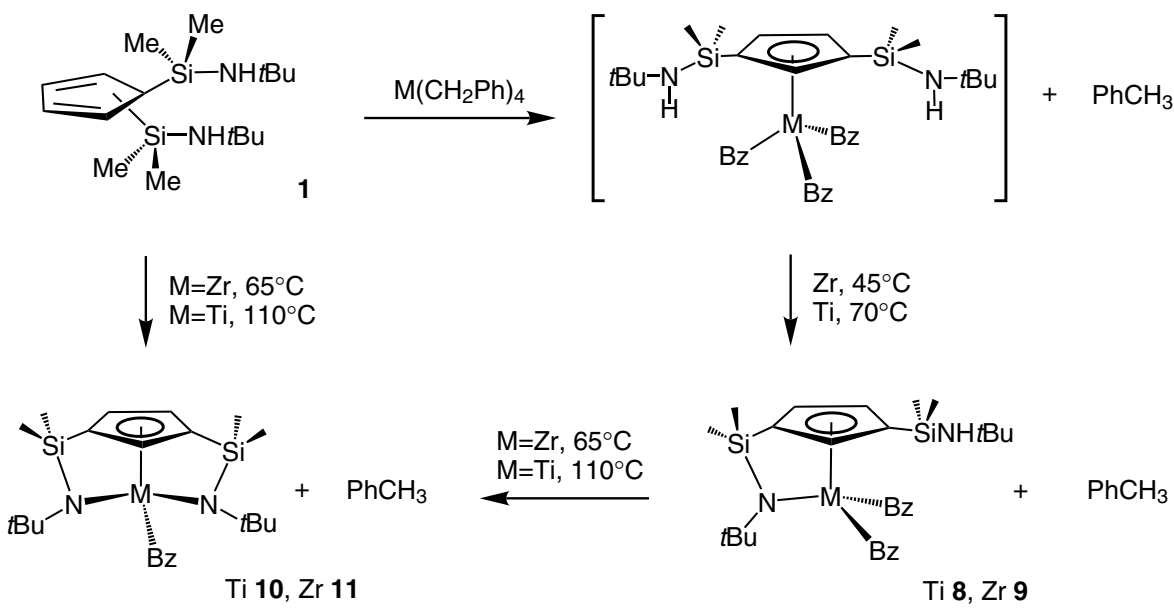

Scheme 3. 


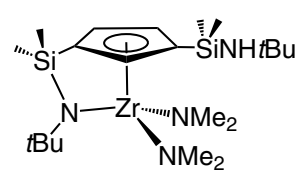

5

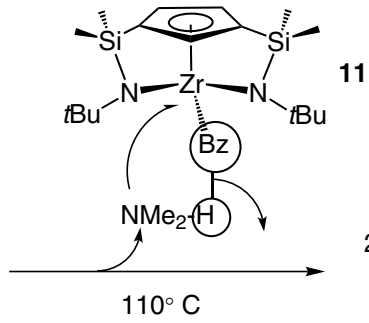

$110^{\circ} \mathrm{C}$

Scheme 4

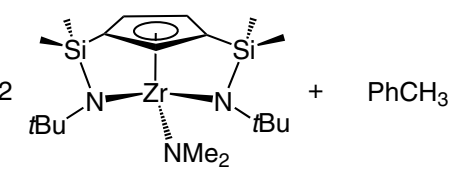

7
The molecular structures of $\mathbf{1 0}$ [18], 13 [24] and $\mathbf{1 6}$ [25] (Fig. 4) were determined by X-ray diffraction methods. The most significant structural feature of $\mathbf{1 0}$ is the orientation of the benzyl ligand, with its phenyl group directed toward the cyclopentadienyl ring. The orientation of the silylamido substituents of complex 13 preventing the nitrogen atoms from acting as donor ligands is also a remarkable feature.

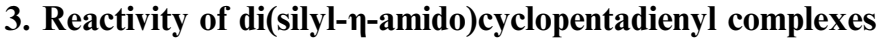

The reactivity of the different types of complex $\left[M\left\{\eta^{5}-\right.\right.$ $\left.\left.\mathrm{C}_{5} \mathrm{H}_{3}-1,3-\left(\mathrm{SiMe}_{2}-\eta-\mathrm{N} t \mathrm{Bu}\right)_{2}\right\} \mathrm{X}\right], \mathrm{M}=\mathrm{Ti}, \mathrm{Zr}$ and $\mathrm{X}=\mathrm{Bz}$, $\mathrm{Me}, \mathrm{NMe}_{2}$, has been studied for: (a) halogenation reactions with protic reagents, (b) insertion of unsaturated substrates into the $\mathrm{M}-\mathrm{N}$ and $\mathrm{M}-\mathrm{C}$ bonds and (c) generation of cationic species and deactivation pathways.

\subsection{Halogenations with protic reagents}

Metal-amido complexes. Synthetic methods for halogenating the $\mathrm{M}-\mathrm{NMe}_{2}$ bonds of the amido complexes $\left[\mathrm{M}\left(\eta^{5}-\mathrm{C}_{5} \mathrm{H}_{4} \mathrm{SiMe}_{2}-\eta^{1}-\mathrm{N} t \mathrm{Bu}\right)\left(\mathrm{NMe}_{2}\right)_{2}\right](\mathrm{M}=\mathrm{Ti}, \mathrm{Zr})$ with $\mathrm{NMe}_{2} \mathrm{H} \cdot \mathrm{HCl}$, leaving the silyl- $\eta^{1}$-amido bridge unaltered had been reported [26]. Whereas this reaction gives the dichloro zirconium derivative, partial simultaneous halogenation of the $\mathrm{Si}-\mathrm{N}$ bond is observed for the titanium derivative to yield the corresponding chlorosilyl- $\eta^{5}$ cyclopentadienyl dichloro-amido titanium complex with amine elimination. In both cases, the liberated amine $\mathrm{NMe}_{2} \mathrm{H}$ remained coordinated to the metal centre.
When a toluene solution containing a mixture of the amido zirconium compound $\left[\mathrm{Zr}\left\{\eta^{5}-\mathrm{C}_{5} \mathrm{H}_{3}\left(\mathrm{SiMe}_{2}-\eta^{1}-\right.\right.\right.$ $\left.\left.\mathrm{N} t \mathrm{Bu})_{2}\right\}\left(\mathrm{NMe}_{2}\right)\right](7)$ and 1 equiv. of $\mathrm{NEt}_{3} \cdot \mathrm{HCl}$ was heated to $70^{\circ} \mathrm{C}$, simultaneous protonation of both the terminal $\mathrm{Zr}-\mathrm{NMe}_{2}$ and one of the bridging $\mathrm{Zr}-\mathrm{N} t \mathrm{Bu}-\mathrm{Si}$ bonds was observed, affording a mixture that contained half of the unchanged starting compound and a new zirconium complex. The starting bis(silyl- $\eta^{1}$-amido) compound was completely transformed into the new zirconium derivative when a second equiv. of $\mathrm{NEt}_{3} \cdot \mathrm{HCl}$ was added (Scheme 6), to give the dichloro compound $\left[\mathrm{Zr}\left\{\eta^{5}-\mathrm{C}_{5} \mathrm{H}_{3}\left[\mathrm{SiMe}_{2}-\right.\right.\right.$ $\left.\left.(\mathrm{NH} t \mathrm{Bu})]\left(\mathrm{SiMe}_{2}-\eta^{1}-\mathrm{N} t \mathrm{Bu}\right)\right\} \mathrm{Cl}_{2}\left(\mathrm{NMe}_{2} \mathrm{H}\right)\right](\mathbf{1 7})$.

Compound 17, which contains the coordinated amine, was also obtained when the same reaction was carried out by addition of 1 equiv. of $\mathrm{NEt}_{3} \cdot \mathrm{HCl}$ to the diamido compound $\left[\mathrm{Zr}\left\{\eta^{5}-\mathrm{C}_{5} \mathrm{H}_{3}\left[\mathrm{SiMe}_{2}(\mathrm{NH} t \mathrm{Bu})\right]\left(\mathrm{SiMe}_{2}-\eta^{1}\right.\right.\right.$ $\mathrm{N} t \mathrm{Bu})\}\left(\mathrm{NMe}_{2}\right)_{2}$ ] (5). Probably, the increased acidity of the metal centre in the resulting chloro-amido intermediate favours the coordination of chloride with protonation and displacement of the second amido group. The reaction was completed affording only pure $\mathbf{1 7}$ after addition of a second equivalent of $\mathrm{NEt}_{3} \cdot \mathrm{HCl}$.

The titanium derivatives $\left[\mathrm{Ti}\left\{\eta^{5}-\mathrm{C}_{5} \mathrm{H}_{3}\left(\mathrm{SiMe}_{2}-\eta^{1}-\right.\right.\right.$ $\left.\left.\mathrm{N} t \mathrm{Bu})_{2}\right\}\left(\mathrm{NMe}_{2}\right)\right]$ (6) and $\left[\mathrm{Ti}\left\{\eta^{5}-\mathrm{C}_{5} \mathrm{H}_{3}\left[\mathrm{SiMe}_{2}(\mathrm{NH} t \mathrm{Bu})\right]-\right.\right.$ $\left.\left.\left(\mathrm{SiMe}_{2}-\eta^{1}-\mathrm{N} t \mathrm{Bu}\right)\right\}\left(\mathrm{NMe}_{2}\right)_{2}\right]$ (4) exhibit similar behaviour. However, the resulting product, $\left[\mathrm{Ti}\left\{\eta^{5}-\mathrm{C}_{5} \mathrm{H}_{3}\left[\mathrm{SiMe}_{2}(\mathrm{NH} t\right.\right.\right.$ $\left.\left.\mathrm{Bu})]\left(\mathrm{SiMe}_{2}-\eta^{1}-\mathrm{N} t \mathrm{Bu}\right)\right\} \mathrm{Cl}_{2}\right]$ (18), which did not contain coordinated amine, was always accompanied by variable, small amounts of a second component that could not be isolated but was identified by NMR spectroscopy as

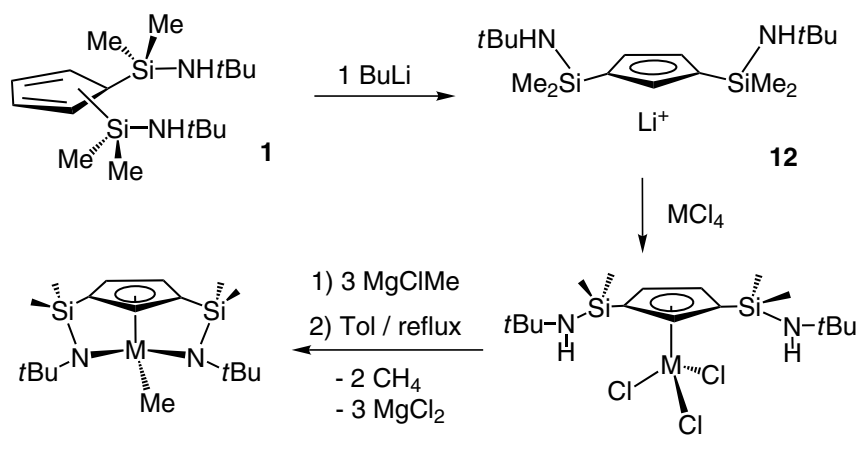

Ti 15, Zr 16 

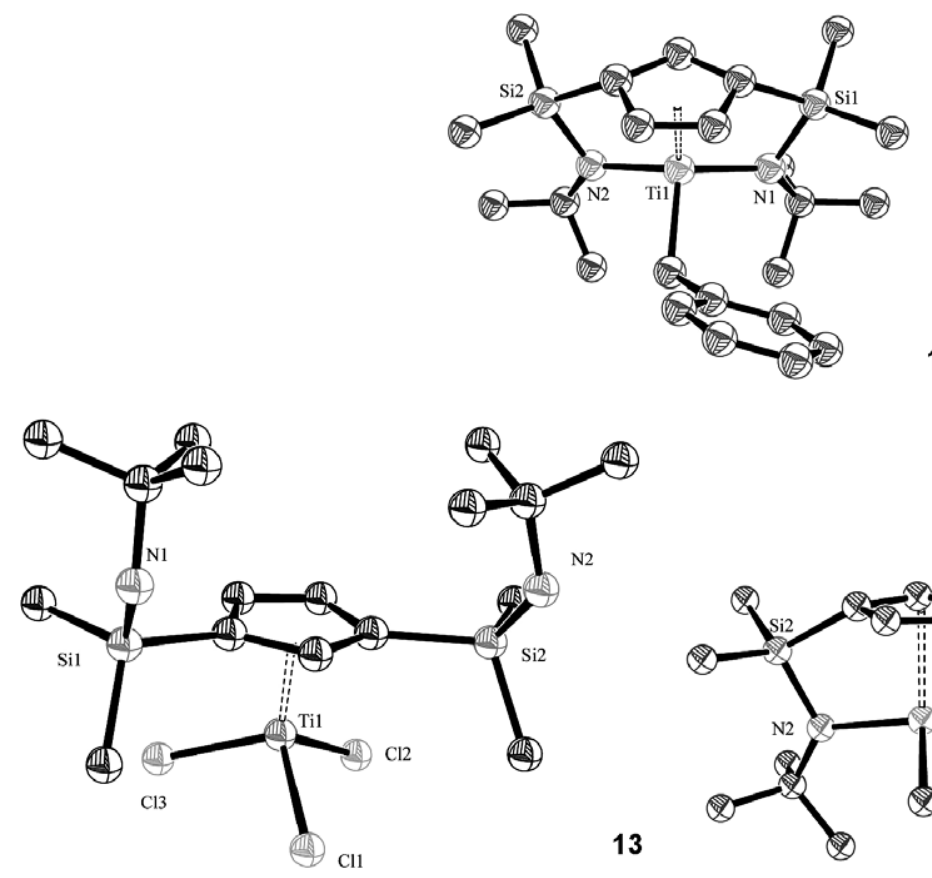

10

Fig. 4. Molecular structures of $\mathbf{1 0}, \mathbf{1 3}$ and $\mathbf{1 6}$.

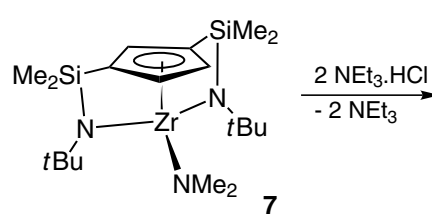

7
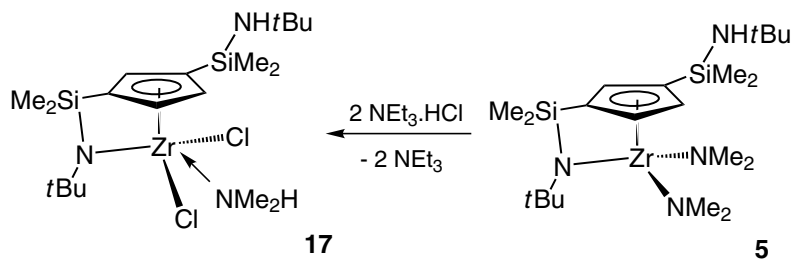

Scheme 6.

$\left[\mathrm{Ti}\left\{\eta^{5}-\mathrm{C}_{5} \mathrm{H}_{3}\left[\mathrm{SiMe}_{2}\left(\mathrm{NMe}_{2}\right)\right]\left(\mathrm{SiMe}_{2}-\eta^{1}-\mathrm{N} t \mathrm{Bu}\right)\right\} \mathrm{Cl}_{2}\right] \quad$ (19). This last compound resulted from a simultaneous exchange reaction between the amino-silyl $\mathrm{Si}-\mathrm{NH} t \mathrm{Bu}$ group of $\mathbf{1 8}$ and the liberated amine $\mathrm{NHMe}_{2}$ (Scheme 7).

Metal-alkyl complexes. Reactions with protic acids are convenient selective methods to achieve high yields of conversion of $\mathrm{M}$-alkyl into $\mathrm{M}$-halide bonds of group 4 metal complexes of the type $\left[\mathrm{M}\left\{\eta^{5}-\mathrm{C}_{5} \mathrm{H}_{4} \mathrm{SiMe}_{2}(\mathrm{~N} t \mathrm{Bu})\right\} \mathrm{R}_{2}\right]$, without alteration of the $\mathrm{Cp}$-silyl- $\eta^{1}$-amido bridging group [27].

The benzyl titanium complex $\left[\mathrm{Ti}\left\{\eta^{5}-\mathrm{C}_{5} \mathrm{H}_{3}\left(\mathrm{SiMe}_{2}-\eta^{1}-\right.\right.\right.$ $\left.\left.\mathrm{N} t \mathrm{Bu})_{2}\right\}\left(\mathrm{CH}_{2} \mathrm{Ph}\right)\right](\mathbf{1 0})$ reacted with 1 equiv. of $\mathrm{NEt}_{3} \cdot \mathrm{HCl}$ in toluene producing the selective protonation of only one of the silyl-amido arms to give the chloro-benzyl derivative $\left[\mathrm{Ti}\left\{\eta^{5}-\mathrm{C}_{5} \mathrm{H}_{3}\left[\mathrm{SiMe}_{2}(\mathrm{NH} t \mathrm{Bu})\right]\left(\mathrm{SiMe}_{2}-\eta^{1}-\mathrm{N} t \mathrm{Bu}\right)\right\} \mathrm{Cl}\left(\mathrm{CH}_{2} \mathrm{Ph}\right)\right]$ (20). Under the same conditions the benzyl-titanium bond was unaltered although it could also be protonated with elimination of toluene when the same reaction was carried out using 2 equiv. of $\mathrm{NEt}_{3} \cdot \mathrm{HCl}$, at $80^{\circ} \mathrm{C}$ for $12 \mathrm{~h}$, to give the dichloro derivative $\left[\mathrm{Ti}\left(\eta^{5}-\mathrm{C}_{5} \mathrm{H}_{3}\left\{\mathrm{SiMe}_{2}(\mathrm{NH} t \mathrm{Bu})\right\}-\right.\right.$ $\left.\left.\left\{\mathrm{SiMe}_{2}\left(\eta^{1}-\mathrm{N} t \mathrm{Bu}\right)\right\}\right) \mathrm{Cl}_{2}\right]$ (21) (Scheme 8).

A similar reaction of the zirconium complex $\left[\mathrm{Zr}\left\{\eta^{5}\right.\right.$ $\left.\left.\mathrm{C}_{5} \mathrm{H}_{3}\left(\mathrm{SiMe}_{2}-\eta^{1}-\mathrm{N} t \mathrm{Bu}\right)_{2}\right\}\left(\mathrm{CH}_{2} \mathrm{Ph}\right)\right]$ (11) was not selective; simultaneous protonation of the $\eta^{1}$-amido and benzyl ligands required the addition of 2 equiv. of $\mathrm{NEt}_{3} \cdot \mathrm{HCl}$, in toluene at $70^{\circ} \mathrm{C}$, to give the dichloro complex $\left[\operatorname{Zr}\left\{\eta^{5}\right.\right.$ $\left.\left.\mathrm{C}_{5} \mathrm{H}_{3}\left[\mathrm{SiMe}_{2}(\mathrm{NH} t \mathrm{Bu})\right]\left(\mathrm{SiMe}_{2}-\eta^{1}-\mathrm{N} t \mathrm{Bu}\right)\right\} \mathrm{Cl}_{2}\right]$ (22), which is similar to $\mathbf{1 7}$ but without coordinated amine.

It is noteworthy that the simultaneous protonolysis of the $\mathrm{Zr}-\mathrm{Bz}$ or $\mathrm{Zr}-\mathrm{NMe}_{2}$ bonds and one of the silyl-amido bridges occurs easily while the second silyl-amido bridge is much more resistant to protonolysis and remains unaltered.

\subsection{Insertion reactions}

Insertion reactions are among the most important organometallic reactions employed to form $\mathrm{C}-\mathrm{C}$ and $\mathrm{C}-\mathrm{N}$ bonds under mild conditions. Many catalytic applications and stoichiometric transformations are based on the products resulting from these basic reactions.

In spite of the low tendency expected for this type of 16 and 18 electron complex [25] to undergo insertion reactions, we have studied the insertion of isocyanides CNR $\left(\mathrm{R}=t \mathrm{Bu}, \quad 2,6-\mathrm{Me}_{2} \mathrm{C}_{6} \mathrm{H}_{3}\right)$ into the metal-amido and metal-alkyl bonds of di(silyl- $\eta$-amido)cyclopentadienyl 

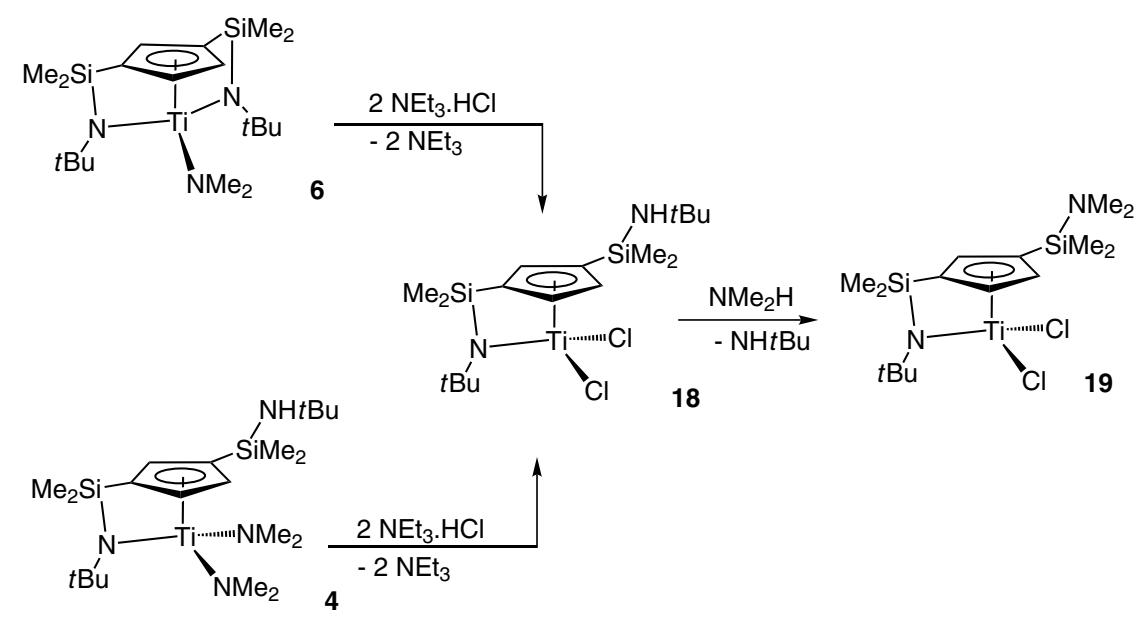

Scheme 7.

titanium and zirconium $\left[\mathrm{M}\left\{\eta^{5}-\mathrm{C}_{5} \mathrm{H}_{3}-1,3-\left(\mathrm{SiMe}_{2}-\eta-\right.\right.\right.$ $\left.\left.\mathrm{N} t \mathrm{Bu})_{2}\right\} \mathrm{R}\right] \quad\left(\mathrm{M}=\mathrm{Ti}, \quad \mathrm{Zr} ; \quad \mathrm{R}=\mathrm{NMe}_{2}, \quad \mathrm{Me}, \quad \mathrm{CH}_{2} \mathrm{Ph}\right)$ complexes.

Metal-amido complexes. As expected the formally 18 electron dimethylamido derivatives $\mathbf{6}$ and $\mathbf{7}$ did not react with $\mathrm{CN} t \mathrm{Bu}$ after being treated for several days at temperatures higher than $100{ }^{\circ} \mathrm{C}$. As shown in Scheme 9, the insertion reaction was only observed for the zirconium complex 7, in spite of its stronger $\mathrm{Zr}-\mathrm{N}$ bond, when its toluene solution was treated with $\mathrm{CN}\left(2,6-\mathrm{Me}_{2} \mathrm{C}_{6} \mathrm{H}_{3}\right)$ and heated for $4 \mathrm{~h}$ at $100{ }^{\circ} \mathrm{C}$, whereas the titanium complex 6 was recovered unchanged under the same conditions. The different reactivity observed for the titanium and zirconium complexes is consistent with the steric hindrance of the bulkier $\mathrm{CN} t \mathrm{Bu}$ ligand and the larger size of the zirconium atom.

The resulting iminocarbamoyl complex $\left[\mathrm{Zr}\left\{\eta^{5}-\mathrm{C}_{5} \mathrm{H}_{3^{-}}\right.\right.$ $\left.\left.1,3-\left(\mathrm{SiMe}_{2}-\eta-\mathrm{N} t \mathrm{Bu}\right)_{2}\right\}\left\{\eta^{2}-\mathrm{C}\left(\mathrm{NMe}_{2}\right)=\mathrm{N}\left(2,6-\mathrm{Me}_{2} \mathrm{C}_{6} \mathrm{H}_{3}\right)\right\}\right]$ (23) was isolated [25] as a yellow oily solid and characterized by elemental analysis and NMR spectroscopy.

Metal-alkyl complexes. Isocyanides $\mathrm{CNR}(\mathrm{R}=t \mathrm{Bu}, 2,6-$ $\mathrm{Me}_{2} \mathrm{C}_{6} \mathrm{H}_{3}$ ) are good $\sigma$-donor ligands that show remarkable differences of reactivity due to their different electrophilic character and steric requirements, the less electronegative and bulkier $\mathrm{R}$ substituents providing the less reactive substrates, particularly for the more hindered titanium compounds. This is consistent with the lower reactivity observed for the more bulky and less electrophilic $\mathrm{CN} t \mathrm{Bu}$ compared to the more reactive $\mathrm{CN}\left(2,6-\mathrm{Me}_{2} \mathrm{C}_{6} \mathrm{H}_{3}\right)$ for any of the insertion reactions studied. Conversely, the higher $\pi$-bonding contribution makes the metal-amido bond more resistant to insertion reactions and with very few exceptions [28] the metal-alkyl bonds undergo preferential insertion of organic isocyanides.

The benzyl complexes $\mathbf{1 0}$ and $\mathbf{1 1}$ did not react when their toluene solutions were heated with $\mathrm{CN} t \mathrm{Bu}$ at temperatures between $20^{\circ} \mathrm{C}$ and $120^{\circ} \mathrm{C}$ for several days. However, insertion of $\mathrm{CN}\left(2,6-\mathrm{Me}_{2} \mathrm{C}_{6} \mathrm{H}_{3}\right)$ into the zirconium-benzyl bond of complex $\mathbf{1 1}$ was observed to give a quantitative conversion into the $\eta^{2}$-iminoacyl complex $\left[\mathrm{Zr}\left\{\eta^{5}-\mathrm{C}_{5} \mathrm{H}_{3}-1,3-\left(\mathrm{SiMe}_{2}-\eta-\mathrm{N} t \mathrm{Bu}\right)_{2}\right\}\left\{\eta^{2}-\mathrm{C}\left(\mathrm{CH}_{2} \mathrm{Ph}\right)=\mathrm{N}(2,6-\right.\right.$ $\left.\left.\mathrm{Me}_{2} \mathrm{C}_{6} \mathrm{H}_{3}\right)\right\}$ ] (24) after heating to $60{ }^{\circ} \mathrm{C}$ for $4 \mathrm{~h}$ (see Scheme 10).

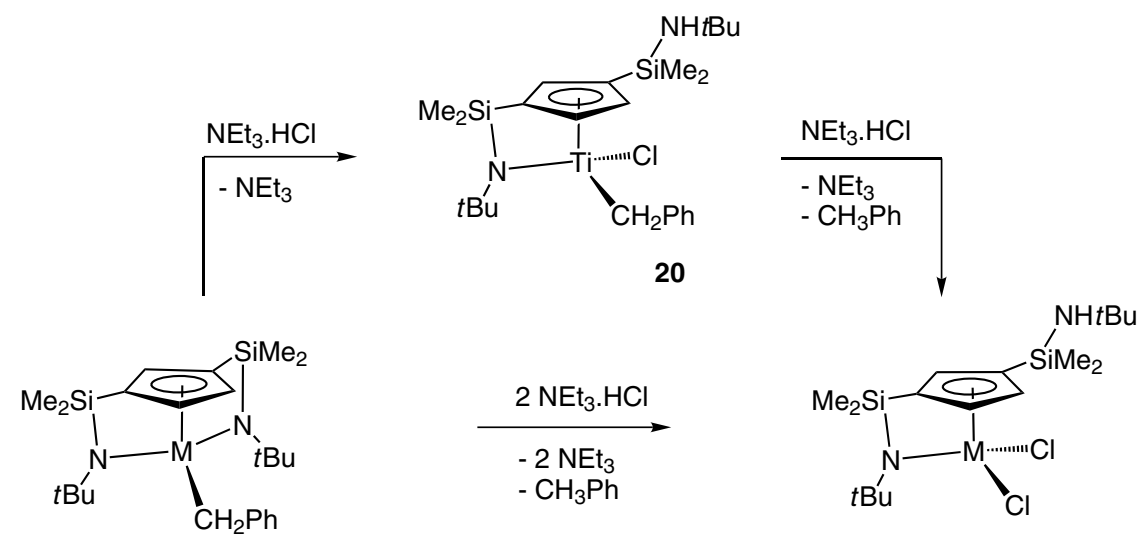




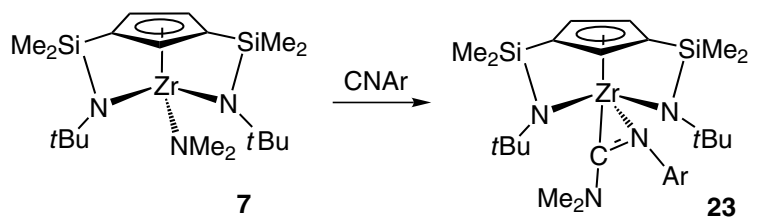

Scheme 9 .

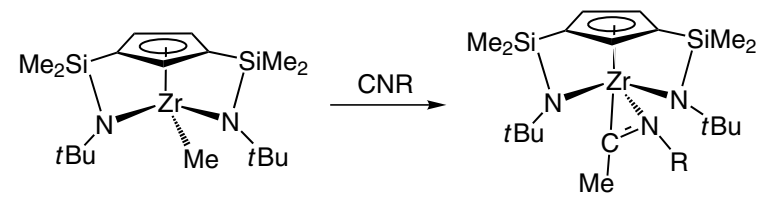

16

$\mathrm{R}=2,6-\mathrm{Me}_{2} \mathrm{C}_{6} \mathrm{H}_{3} 25, t \mathrm{Bu} 26$

Scheme 11.

The insertion of isocyanide was feasible for both zirconium and titanium complexes $\mathbf{1 5}$ and $\mathbf{1 6}$ when the isocyanides $\mathrm{CNR}\left(\mathrm{R}=2,6-\mathrm{Me}_{2} \mathrm{C}_{6} \mathrm{H}_{3}, t \mathrm{Bu}\right)$ were used. As shown in Scheme 11, addition of 1 equiv. of CNR to toluene solutions of the zirconium complex 16 gave the iminoacyl complexes $\left[\mathrm{Zr}\left\{\eta^{5}-\mathrm{C}_{5} \mathrm{H}_{3}-1,3-\left(\mathrm{SiMe}_{2}-\eta-\mathrm{N} t \mathrm{Bu}\right)_{2}\right\}\left(\eta^{2}-\right.\right.$ $\mathrm{CMe}=\mathrm{NR})]\left(\mathrm{R}=2,6-\mathrm{Me}_{2} \mathrm{C}_{6} \mathrm{H}_{3}, 25 ; t \mathrm{Bu}, 26\right)$. Formation of 25 proceeded cleanly at room temperature whereas heating at $50{ }^{\circ} \mathrm{C}$ was required to obtain $\mathbf{2 6}$ and complete transformation was observed after $12 \mathrm{~h}$. The ${ }^{1} \mathrm{H}$ and ${ }^{13} \mathrm{C} \mathrm{NMR}$ spectra are consistent with the structure proposed for complex 26 with two symmetric silyl- $\eta$-amido arms and the $\eta^{2}$ iminoacyl ligand located in the plane of symmetry.

While no reaction with $\mathrm{CN} t \mathrm{Bu}$ occurred for the methyl titanium complex 15, a slow and more complex reaction was observed when 1 equiv. of $\mathrm{CN}\left(2,6-\mathrm{Me}_{2} \mathrm{C}_{6} \mathrm{H}_{3}\right)$ was added to a toluene solution of complex 15 heated to $75^{\circ} \mathrm{C}$ for $24 \mathrm{~h}$. As shown in Scheme 12, the insertion led initially to the formation of the corresponding iminoacyl complex 27, unreacted starting material and a new compound 28 which was the unique reaction product when excess $\mathrm{CN}\left(2,6-\mathrm{Me}_{2} \mathrm{C}_{6} \mathrm{H}_{3}\right)$ was added and the reaction mixture was heated at $120^{\circ} \mathrm{C}$ for $24 \mathrm{~h}$. Pure compound 27 could not be isolated whereas the new complex $\mathbf{2 8}$ was formed via a double insertion reaction that afforded $\eta^{2}$ iminoacyl and $\eta^{2}$-iminocarbamoyl ligands, which undergo a further $\mathrm{C}=\mathrm{C}$ coupling reaction to produce an asymmetrical bicyclic enediamido complex.

The formation of the intermediate iminoacyl-iminocarbamoyl compound was detected when the reaction was monitored by ${ }^{13} \mathrm{C}$ NMR spectroscopy in a Teflon-valved NMR tube. After heating at $90{ }^{\circ} \mathrm{C}$ for $48 \mathrm{~h}$, a mixture of 27, 28 and the intermediate complex was observed and identified by the characteristic $\eta^{2}$-iminoacyl and $\eta^{2}$-iminocarbamoyl ${ }^{13} \mathrm{C}$ NMR signals.
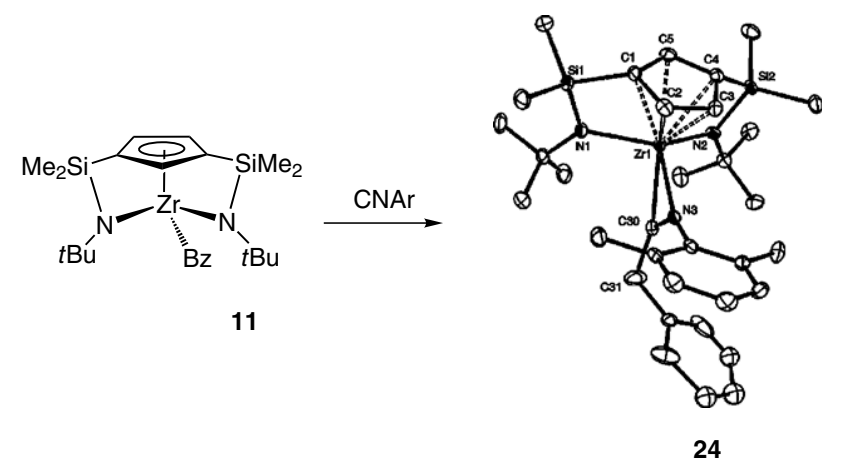

Scheme 10 .
This is an example of a coupling reaction between iminoacyl and iminocarbamoyl ligands giving a type of the known diazabutadiene complexes containing a 2-methyl3-amido-dad ligand in which $\operatorname{TiN}_{2} \mathrm{C}_{2}$ framework "flipping" is prevented by the bond to the pendant silyl- $\eta$-amido bridge. The ${ }^{13} \mathrm{C}$ NMR spectrum of $\mathbf{2 8}$ is consistent with the presence of an asymmetric chelating $-\mathrm{N}-C=C-\mathrm{N}-$ moiety.

The molecular structures of complexes $\mathbf{2 4}$ and $\mathbf{2 8}$ were determined by X-ray diffraction methods.

The structure found for complex 24 (Scheme 10) [25] confirmed that the zirconium centre shows a profoundly distorted trigonal bipyramidal coordination in which the equatorial plane is defined by the iminoacyl and the two silylamido nitrogen atoms and the apical positions are occupied by the cyclopentadienyl ring and the iminoacyl carbon atom in contrast to the pseudo-square-pyramidal coordination [29] found for the mono-insertion product in singly bridged compounds. Double insertion in the dialkyl derivative $\left[\mathrm{Zr}\left\{\eta^{5}-\mathrm{C}_{5} \mathrm{Me}_{4}\left(\mathrm{SiMe}_{2}-\eta-\mathrm{N} t \mathrm{Bu}\right)\right\} \mathrm{Me}_{2}\right]$ afforded a pseudo-octahedral configuration [30] in which, one atom of the iminoacyl groups occupies the axial or the equatorial position, depending on the $\mathrm{R}$ substituent of the isocyanide. When $\mathrm{R}=t \mathrm{Bu}$, one of the imido- $\mathrm{N}$ atoms is in the axial position trans to the cyclopentadienyl ring, whereas when $\mathrm{R}$ is a less sterically demanding group (2,6$\mathrm{Me}_{2} \mathrm{C}_{6} \mathrm{H}_{3}$ ), one of the imido- $\mathrm{N}$ fragments is located in the equatorial plane.

The ${ }^{13} \mathrm{C}$ NMR spectrum is also consistent with this proposal and provides additional evidence for the high electron density of the metal resulting from the $\eta^{2}$-coordination of the iminoacyl ligand, as shown by the low value of the difference $\Delta \delta$ which is an indication of the low $\pi$-bonding contribution of the bridging silylamido ligand [25].

The molecular structure of 28 [25] (Fig. 5) shows the titanium atom at the centre of a distorted pseudotetrahedral coordination with the five-membered $\mathrm{TiN}_{2} \mathrm{C}_{2}$ ring of the dad ligand folded along the $\mathrm{N}(3)-\mathrm{N}(4)$ axis providing the less favourable prone orientation observed for dad-Ti $(\mathrm{dad}=\mathrm{RN}-\mathrm{CH}=\mathrm{CH}-\mathrm{NR}) \quad$ compounds in solution [31,32], forced by the bond to the pendant amido group, in contrast with the supine conformation reported for group 4 enediamido complexes [30-33].

In summary, we may conclude that the reactivity of the metal-benzyl bonds is similar to that observed for the related metal-amido bonds, despite being formally 

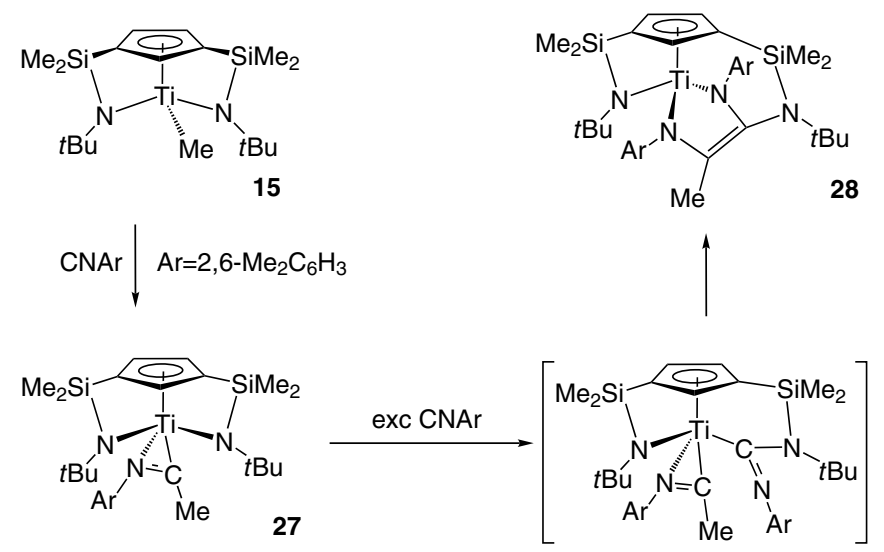

$+15+28$

Scheme 12.

16-electron compounds with one vacant metal orbital. In contrast, the $\mathrm{M}-\mathrm{Me}$ bonds are sterically less protected and more reactive.

The reactivity found for $\mathrm{CN}\left(2,6-\mathrm{Me}_{2} \mathrm{C}_{6} \mathrm{H}_{3}\right)$ is consistent with its $\sigma$-donor character, whereas the steric hindrance of the bulkier $\mathrm{CN} t \mathrm{Bu}$ ligand may explain its lack of reactivity. Similar electronic effects together with the smaller atomic radius of titanium and the steric requirements of the ligands used for insertion may be invoked to justify the lack of reactivity of the benzyl-titanium complex $\mathbf{1 0}$.

\subsection{Cationic compounds}

Addition of $\mathrm{C}_{6} \mathrm{D}_{6}$ by vacuum transfer to a Teflon-valved NMR tube containing a mixture of $\mathrm{B}\left(\mathrm{C}_{6} \mathrm{~F}_{5}\right)_{3}$ and the alkyl derivatives 10, 11, 15 and $\mathbf{1 6}$ in a 1:1 molar ratio immediately gave the partially soluble cationic species $\left[\mathrm{M}\left(\eta^{5}\right.\right.$ $\left.\left.\mathrm{C}_{5} \mathrm{H}_{3}\right)\left(\mathrm{SiMe}_{2}-\eta^{1}-\mathrm{N} t \mathrm{Bu}\right)_{2}\right]^{+}$, isolated as $\left[\mathrm{B}(\mathrm{R})\left(\mathrm{C}_{6} \mathrm{~F}_{5}\right)_{3}\right]^{-}$salts $[\mathrm{M}=\mathrm{Ti}, \mathrm{R}=\mathrm{Bz}$ 29; $\mathrm{M}=\mathrm{Zr}, \mathrm{R}=\mathrm{Bz}$ 30; $\mathrm{M}=\mathrm{Ti}, \mathrm{R}=\mathrm{Me}$ 31; $\mathrm{M}=\mathrm{Zr}, \mathrm{R}=\mathrm{Me}$ 32] [17,18].

The structures of these cations in $\mathrm{C}_{6} \mathrm{D}_{6}$ solutions were established by NMR studies. Their ${ }^{1} \mathrm{H}$ and ${ }^{13} \mathrm{C}$ NMR spectra being consistent with the $C_{S}$ symmetry also observed for the neutral benzyl and methyl precursor compounds 10-11 and 15-16.

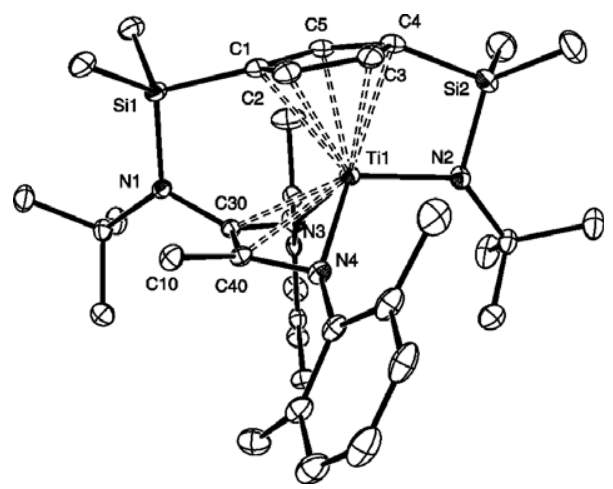

Fig. 5. Molecular structure of complex 28.
Surprising behaviour was observed [21-23] when the ${ }^{1} \mathrm{H}$ and ${ }^{13} \mathrm{C}$ NMR spectra of the neutral benzyl precursor compounds 10 and 11 were compared with those of the corresponding cationic titanium and zirconium derivatives 29 and $\mathbf{3 0}$ as all of the NMR resonances for the cationic species were shifted upfield. This unexpected behaviour seems to be associated with the anisotropy due to the benzyl ring. The structures of complexes 29 and 30, were determined by Xray diffraction methods $[17,18]$ and perspective views of their molecular structures are shown in Fig. 6. The pseudo-tetrahedral geometry about $\mathrm{Ti}$ and $\mathrm{Zr}$ in 29 and 30 is defined by the centroid of the cyclopentadienyl ring and the two $\mathrm{N}$-donors of the appended (dimethylsilyl)amido arms, with the remaining coordination site occupied by the meta-C atom of the benzylborate phenyl ring indicating an interaction of its $\mathrm{p} \pi$ orbital with the empty hybrid metal orbital [34-36].

The most significant feature of this structure is that the phenyl ring is oriented upward in the direction of the cyclopentadienyl ring, as also observed for the benzyl substituent in complex 10. DFT calculations for these species [18] were described to provide an explanation for the unusual $\eta^{1}$ coordination of the phenyl ring to the group 4 metal cations.

\section{Catalytic activity and deactivation of cationic compounds}

Catalytic activity for ethene polymerization was observed for complex $\mathbf{3 0}$ despite its being an alkyl-free cationic species, when a valved Schlenk tube containing its toluene solution was filled with ethene at room temperature and pressure [37]. Higher activity $\left(740 \mathrm{~kg} \mathrm{PE}(\mathrm{mol} \mathrm{Zr})^{-1}\right.$ $\mathrm{h}^{-1} \mathrm{~atm}^{-1}$ ) was measured in $n$-hexane at $4 \mathrm{~atm}$ ethylene and $70^{\circ} \mathrm{C}$ for the neutral benzyl complex 11 after being activated with methylaluminoxane to give a rather high molecular weight $\left(M_{\mathrm{w}}=540,000\right)$ PE with a polydispersity of $M_{\mathrm{w}} / M_{\mathrm{n}}=1.9$. Complex 11 was also an active catalyst $\left(350 \mathrm{~kg} \mathrm{PE}(\mathrm{mol} \mathrm{Zr})^{-1} \mathrm{~h}^{-1} \mathrm{~atm}^{-1}\right)$ for the copolymerization of ethene and 1-hexene to give a polymer containing $0.7 \%$ of 1-hexene. 

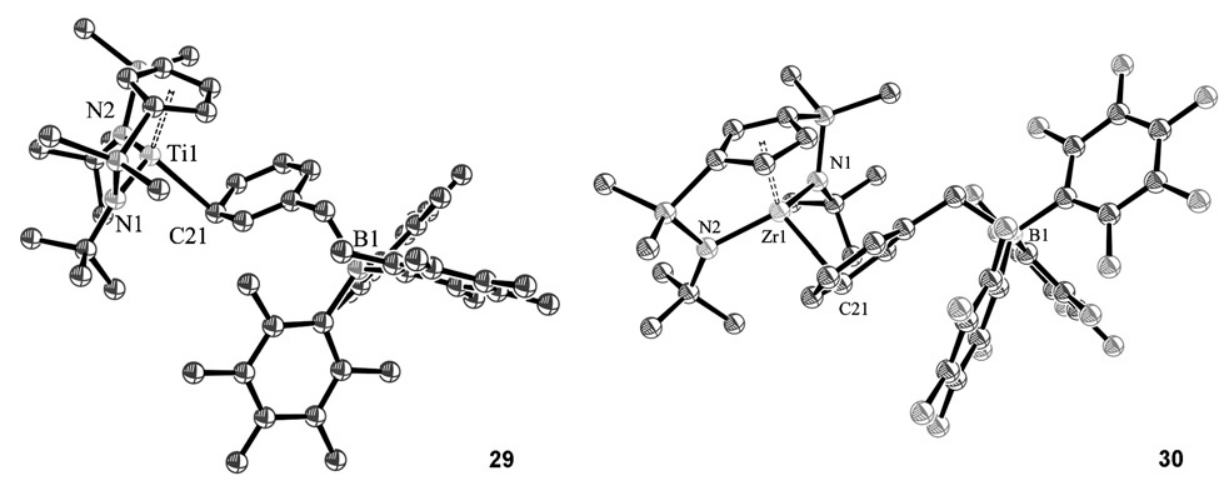

Fig. 6. Molecular structures of $\mathbf{2 9}$ and $\mathbf{3 0 .}$

It is well known that ionic group 4 metal complexes of the type $\left[\mathrm{L}_{2} \mathrm{MR}\right]\left[\mathrm{RB}\left(\mathrm{C}_{6} \mathrm{~F}_{5}\right)_{3}\right]$ are used as catalysts for olefin polymerization $[8,38,39]$. Weakly coordinating anions with fluoroorganic moieties are usually employed to minimize the ion-pairing interactions. However, these $\left[\mathrm{RB}\left(\mathrm{C}_{6} \mathrm{~F}_{5}\right)_{3}\right]^{-}$groups can still be responsible for deactivation processes. The most reactive bond of this anion is the $\mathrm{B}-\mathrm{C}$ bond and $\mathrm{C}_{6} \mathrm{~F}_{5}$ transfer to the cationic metal centre [40-46] is the most commonly observed deactivation pathway for this type of cationic alkyl $\left[\mathrm{L}_{2} \mathrm{MR}\right]\left[\mathrm{RB}\left(\mathrm{C}_{6} \mathrm{~F}_{5}\right)_{3}\right]$ catalyst. Ziegler and co-workers have recently reported theoretical calculations on different competing thermal deactivation pathways for the $\left[\mathrm{L}_{2} \mathrm{MR}\right]\left[\mathrm{RB}\left(\mathrm{C}_{6} \mathrm{~F}_{5}\right)_{3}\right]$ ion pair $[47,48]$.

We have studied the reaction pathways followed when the alkyl-free cationic complexes $\left[\mathrm{Zr}\left\{\mathrm{C}_{5} \mathrm{H}_{3}\left[\mathrm{SiMe}_{2}-\right.\right.\right.$ $\left.\left.\left.\left(\eta^{1}-\mathrm{N} t \mathrm{Bu}\right)\right]_{2}\right\}\right]\left[\mathrm{RB}\left(\mathrm{C}_{6} \mathrm{~F}_{5}\right)_{3}\right]$ are heated in the absence or presence of triphenylphosphane [19]. Complexes $\mathbf{3 0}$ and
32 were thermally stable upon heating their solutions for several hours up to $80^{\circ} \mathrm{C}$. However, addition of 1 equiv. of $\mathrm{PPh}_{3}$ to the $\mathrm{C}_{6} \mathrm{D}_{6}$ solutions of $\mathbf{3 0}$ and $\mathbf{3 2}$ at room temperature gave a suspension of an insoluble solid which upon heating at $80{ }^{\circ} \mathrm{C}$ for several days afforded a mixture containing compounds $\mathbf{3 3}$ and $\mathbf{3 4}$. When the insoluble solid formed at room temperature was separated by filtration, suspended in fresh $\mathrm{C}_{6} \mathrm{D}_{6}$ and heated at $80^{\circ} \mathrm{C}$ for 7 days compound $\mathbf{3 3}$ was obtained. These compounds could be generated by transfer of $\mathrm{F}$ and $\mathrm{C}_{6} \mathrm{~F}_{5}$ to zirconium, respectively, although their formation and structure were only confirmed when they were obtained by alternative synthetic methods (Scheme 13).

Complex $\quad\left[\mathrm{Zr}\left\{\mathrm{C}_{5} \mathrm{H}_{3}\left[\mathrm{SiMe}_{2}\left(\eta^{1}-\mathrm{N} t \mathrm{Bu}\right)\right]_{2}\right\} \mathrm{F}\right] \quad$ (33) was obtained when the zirconium alkyl complex $\left[\mathrm{Zr}\left\{\mathrm{C}_{5} \mathrm{H}_{3}[\mathrm{Si}\right.\right.$ $\left.\left.\left.\mathrm{Me}_{2}\left(\eta^{1}-\mathrm{N} t \mathrm{Bu}\right)\right]_{2}\right\}\left(\mathrm{CH}_{2} \mathrm{Ph}\right)\right](\mathbf{1 1})$ was treated with $\mathrm{FSnPh}_{3}$ [49] in toluene at $80^{\circ} \mathrm{C}$ for $5 \mathrm{~h}$. The $[\mathrm{Zr}]-\mathrm{C}_{6} \mathrm{~F}_{5}(\mathbf{3 4})$ complex was obtained following a different reaction pathway. The

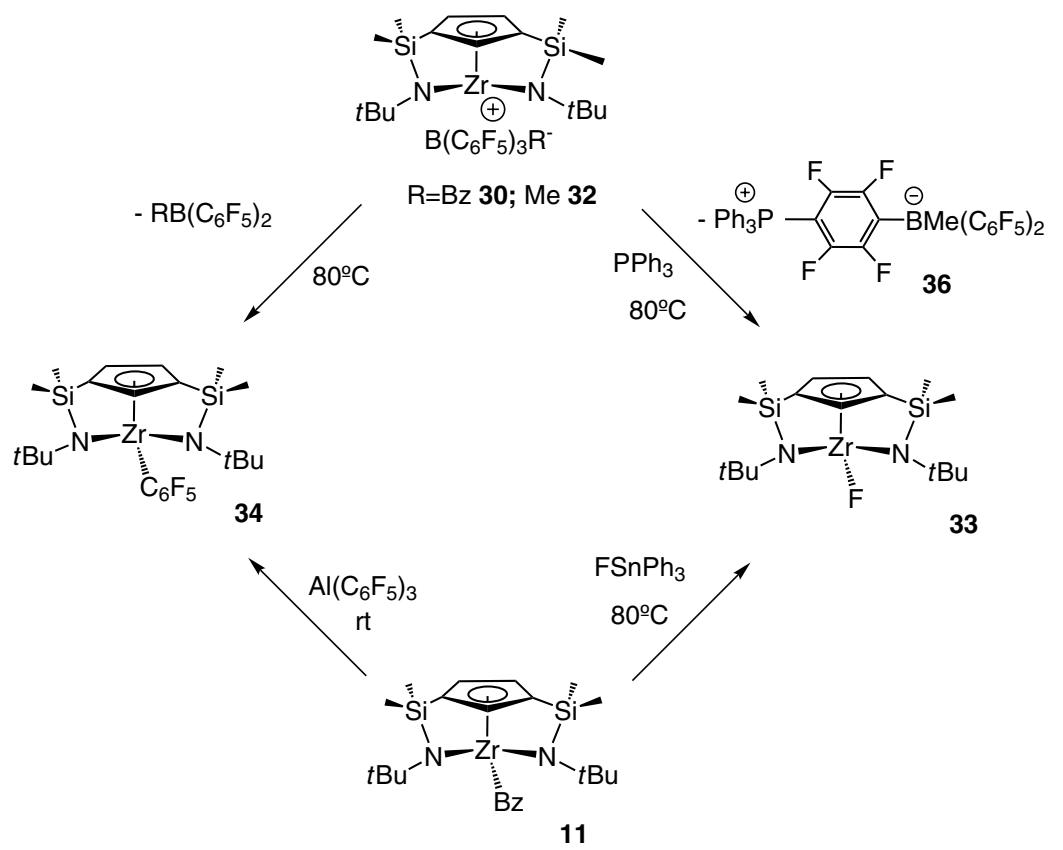

Scheme 13. 


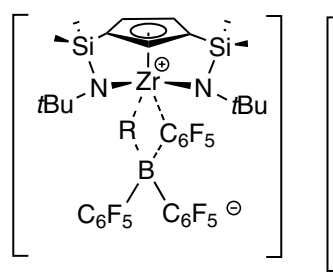

A

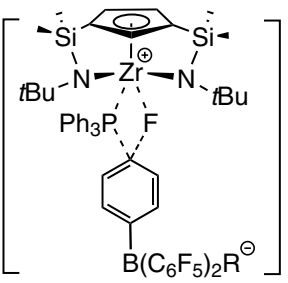

B
Scheme 14. Possible activated species responsible of direct $\mathrm{C}_{6} \mathrm{~F}_{5}$ and $\mathrm{F}$ transfer.

reaction of 11 with $\mathrm{Al}\left(\mathrm{C}_{6} \mathrm{~F}_{5}\right)_{3}$ proceeded at $25^{\circ} \mathrm{C}$ with abstraction of the benzyl ligand to give the cationic zirconium complex $\quad\left[\mathrm{Zr}\left\{\mathrm{C}_{5} \mathrm{H}_{3}\left[\mathrm{SiMe}_{2}\left(\eta^{1}-\mathrm{N} t \mathrm{Bu}\right)\right]_{2}\right\}\right]\left[\left(\mathrm{CH}_{2}-\right.\right.$ $\left.\mathrm{Ph}) \mathrm{Al}\left(\mathrm{C}_{6} \mathrm{~F}_{5}\right)_{3}\right]$ with simultaneous formation of a small amount of $\left[\mathrm{Zr}\left\{\mathrm{C}_{5} \mathrm{H}_{3}\left[\mathrm{SiMe}_{2}\left(\eta^{1}-\mathrm{N} t \mathrm{Bu}\right)\right]_{2}\right\}\left(\mathrm{C}_{6} \mathrm{~F}_{5}\right)\right]$ (34). Quantitative $\mathrm{C}_{6} \mathrm{~F}_{5}$ transfer was complete after $12 \mathrm{~h}$ to give 34 as the unique reaction product, isolated as a crystalline solid. The molecular structure of $\mathbf{3 4}$ was determined by diffraction methods [19].

The moiety responsible for the intramolecular $\mathrm{B}-\mathrm{C}_{6} \mathrm{~F}_{5}$ bond activation and the $\mathrm{C}_{6} \mathrm{~F}_{5}$ transfer to the metal with elimination of the neutral borane $\mathrm{RB}\left(\mathrm{C}_{6} \mathrm{~F}_{5}\right)_{2}$ [50] could be the methyl bridged ion pair system $\mathrm{A}$ represented in Scheme 14. This is a slow reaction that takes place when the cationic complexes $\mathbf{3 0}$ and $\mathbf{3 2}$ are heated at $80^{\circ} \mathrm{C}$ for 7 days to give complex 34. When the same reaction takes place in the phosphane coordinated cationic complex $\left[\mathrm{Zr}\left\{\mathrm{C}_{5} \mathrm{H}_{3}\left[\mathrm{SiMe}_{2}\left(\eta^{1}-\mathrm{N} t \mathrm{Bu}\right)\right]_{2}\right\}\left\{\mathrm{PPh}_{3}\right\}\right]^{+}\left[(\mathrm{R}) \mathrm{B}\left(\mathrm{C}_{6} \mathrm{~F}_{5}\right)_{3}\right]^{-} \quad$ a different deactivation process occurred by transfer of the $p$-fluoride of one of the pentafluorophenyl borate rings to the metal. The thermal transformations may occur by nucleophilic addition of $\mathrm{PPh}_{3}$ to the $p-\mathrm{C}-\mathrm{F}$ bond of one of the electron-deficient $\mathrm{C}_{6} \mathrm{~F}_{5}$ rings [51,52] of the metalcoordinated alkylborate counteranion $\left[\mathrm{RB}\left(\mathrm{C}_{6} \mathrm{~F}_{5}\right)_{3}\right]^{-}$with immediate transfer of the fluoride generated [53] to the zirconocenium cation (pair system B, Scheme 14) to give 33.

In agreement with this proposal we never observed conversion of 34 into 33 [53].

In addition, heating an equimolar mixture of $\mathbf{3 0}$ and $\mathrm{PPh}_{3}$ to $50{ }^{\circ} \mathrm{C}$ for 7 days gave a mixture from which a colourless monocrystal identified as complex $\mathbf{3 5}$ was isolated [19]. The molecular structure of this compound from X-ray diffraction studies revealed that it contained a separate $\mu-\mathrm{F}$ bridged dinuclear cation $\left[\left(\mathrm{Zr}_{\{} \mathrm{C}_{5} \mathrm{H}_{3}[\mathrm{Si}-\right.\right.$ $\left.\left.\left.\left.\mathrm{Me}_{2}\left(\eta^{1}-\mathrm{N}^{t} \mathrm{Bu}\right)\right]_{2}\right\}\right)_{2} \mathrm{~F}\right]^{+}$and the free $\mathrm{B}\left(\mathrm{C}_{6} \mathrm{~F}_{5}\right)_{3} \mathrm{Bz}^{-}$anion (Fig. 7).

When a mixture of equimolar amounts of $\mathbf{3 2}$ and $\mathrm{PPh}_{3}$ was heated at $80^{\circ} \mathrm{C}$ for 7 days crystals of the zwitterionic compound 36 suitable for X-ray diffraction studies were isolated [19]. The molecular structure of compound $\mathbf{3 6}$ (Fig. 8) provides additional evidence to this reaction pathway as it shows the presence of triphenylphosphonium and methyl-bis(pentafluorophenyl)borate fragments located at the para-positions of the resulting tetrafluorophenyl acti-

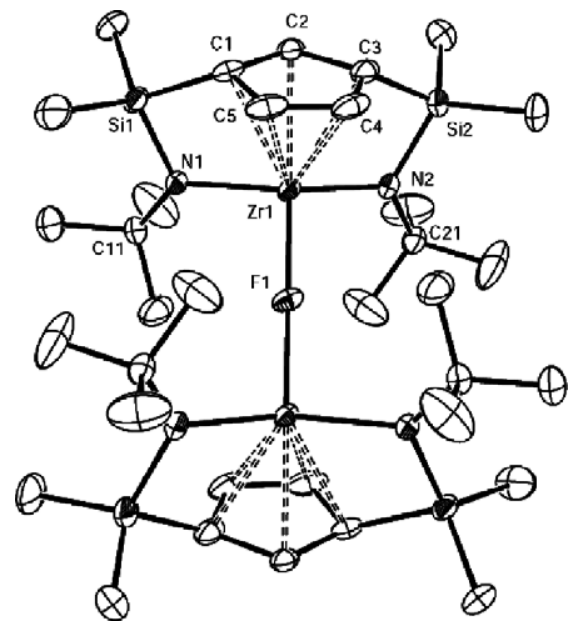

Fig. 7. ORTEP view of the dinuclear cation of $\mathbf{3 5}$ with $30 \%$ probability ellipsoids.

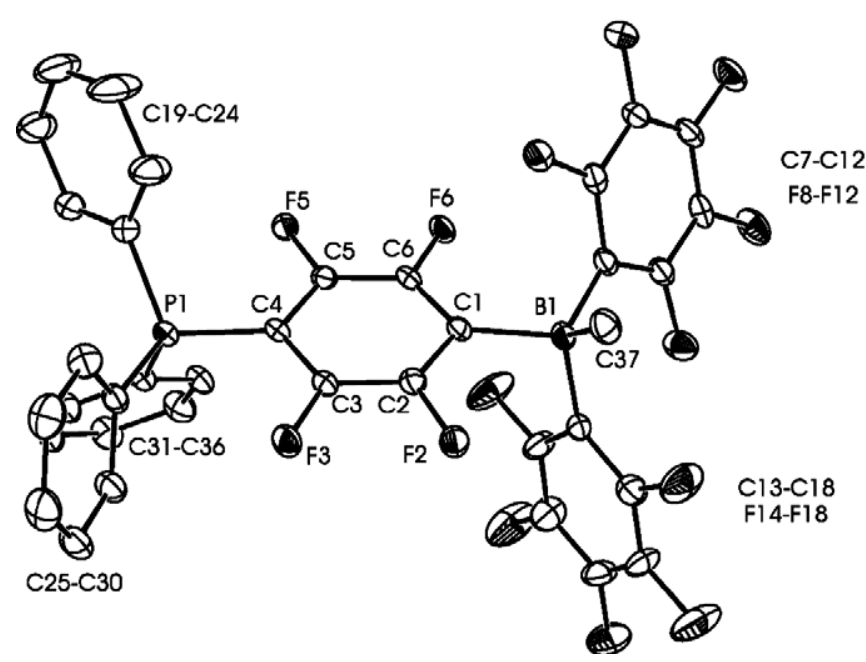

Fig. 8. ORTEP view of $\mathbf{3 6}$ with $30 \%$ probability ellipsoids.

vated ring. A similar example of an aryl phosphoniumborate $\mathrm{R}_{3} \mathrm{P}-\mathrm{C}_{6} \mathrm{X}_{4}-\mathrm{BR}_{3}$ structure has been recently reported [52].

\section{Conclusions}

A new class of group 4 metal complexes with a tridentate ligand with two silyl- $\eta$-amido groups tethered to a cyclopentadienyl ring has been isolated by deprotonation of the di(aminosilyl)cyclopentadiene with basic $\mathrm{MX}_{4}(\mathrm{M}=\mathrm{Ti}$, $\mathrm{Zr} ; \mathrm{X}=\mathrm{CH}_{2} \mathrm{Ph}, \mathrm{NMe}_{2}$ ) compounds and by deprotonation of the di(silylamino) groups of the monocyclopentadienyl metal trichloro complexes with excess $\mathrm{MgMeCl}$.

The halogenation reactions of the terminal $\mathrm{M}-\mathrm{N}$ and $\mathrm{M}-\mathrm{R}$ bonds with protic reagents take place easily with simultaneous opening of one the silyl- $\eta$-amido bridges whereas the second bridge remains unaltered.

The reactivity observed in the insertion of isocyanides into the alkyl and amido di(silyl- $\eta$-amido)cyclopentadienyl titanium and zirconium complexes demonstrates that the 
insertions into the terminal $\mathrm{M}-\mathrm{N}$ and $\mathrm{M}-\mathrm{C}$ bonds is preferred to the insertion into the $\mathrm{M}-\mathrm{N}$ bonds of the silyl- $\eta$ amido bridges.

The alkyl derivatives of this type of complex when activated with MAO are efficient catalysts for ethene polymerization and ethene-1-hexene copolymerization, despite generating 14-electron alkyl-free $\mathrm{d}^{0}$ cationic species without the alkyl group required for the typical Ziegler-Natta insertion reaction. Similar observations have been made with related metal cationic species without alkyl groups, which also show ethene polymerization activity $[11,13,15]$.

The stability observed for the corresponding cationic species at room temperature demonstrates that the di(silyl- $\eta$-amido)cyclopentadienyl titanium and zirconium complexes have a rather low acidic character and are appropriate candidates to study the reactivity of the active species. We observed the deactivation of the cationic species by transfer to the metal of the $\mathrm{C}_{6} \mathrm{~F}_{5}$ group from the borate anion and we could also demonstrate that direct fluoride migration without previous $\mathrm{C}_{6} \mathrm{~F}_{5}$ transfer is a feasible deactivation pathway for zirconocenium catalysts. In contrast, it is noteworthy that the opening of the silylamido bridges was not observed during the course of these activations.

In summary, besides the absence of the alkyl group required for the first step of the polymerization process which is the main difference between constrained geometry cationic complexes with one or two silylamido bridges (CGC), we can conclude that doubly bridged species posses a less acidic metal centre that facilitates the study of the cations assumed to be the active species in the polymerization process at room temperature or even higher temperatures, in contrast to the high instability observed at room temperature for the mono-bridged cationic complexes.

\section{Acknowledgments}

We gratefully acknowledge Ministerio de Educación y Ciencia (Project MAT2004-02614 and programme J. de la Cierva) and DGUI-Comunidad de Madrid (Programme S-0505/PPQ-0328, COMAL-CM) (Spain) for financial support.

\section{References}

[1] P.J. Shapiro, E. Bunel, W.P. Schaefer, J.E. Bercaw, Organometallics 9 (1990) 867.

[2] W.E. Piers, P.J. Shapiro, E.E. Bunel, J.E. Bercaw, Synlett (1990) 74.

[3] J. Okuda, Chem. Ber. 123 (1990) 1649.

[4] J.C. Stevens, F.J. Timmers, D.R. Wilson, G.F. Schmidt, P.N. Nickias, R.K. Rosen, G.W. Knight, S. Lai, Eur. Patent. Appl. EP (1991) 416.

[5] J.M. Canich, Eur. Patent. Appl. EP (1991) 420.

[6] P.J. Shapiro, W.D. Cotter, W.P. Schaefer, J.A. Labinger, J.E. Bercaw, J. Am. Chem. Soc. 116 (1994) 4623.

[7] H.H. Brintzinger, D. Fischer, R. Mülhaupt, B. Rieger, R.M. Waymouth, Angew. Chem., Int. Ed. Engl. 34 (1995) 1143.

[8] M. Bochmann, J. Chem. Soc., Dalton Trans. (1996) 255.

[9] A.L. McKnight, R.M. Waymouth, Chem. Rev. 98 (1998) 2587.
[10] H. Braunschweig, F.M. Breitling, Coord. Chem. Rev. 250 (2006) 2691.

[11] J.Z. Jin, D.R. Wilson, E.Y.X. Chen, Chem. Commun. (2002) 708 .

[12] V.C. Gibson, M.J. Humphries, K.P. Tellmann, D.F. Wass, A.J.P. White, D.J. Williams, Chem. Commun. (2001) 2252.

[13] M.J. Humphries, K.P. Tellmann, V.C. Gibson, A.J.P. White, D.J. Williams, Organometallics 24 (2005) 2039.

[14] T.M. Kooistra, Q. Knijnenburg, J.M.M. Smits, A.D. Horton, P.H.M. Budzelaar, A.W. Gal, Angew. Chem., Int. Ed. 40 (2001) 4719.

[15] W. Steffen, T. Blömker, N. Kleigrewe, G. Kehr, R. Fröhlich, G. Erker, Chem. Commun. (2004) 1188.

[16] N. Kleigrewe, W. Steffen, T. Blömker, G. Kehr, R. Fröhlich, B. Wibbeling, G. Erker, J.C. Wasilke, G. Wu, G.C. Bazan, J. Am. Chem. Soc. 127 (2005) 13955.

[17] J. Cano, P. Royo, M. Lanfranchi, M.A. Pellinghelli, A. Tiripicchio, Angew. Chem., Int. Ed. 40 (2001) 2495.

[18] J. Cano, P. Royo, H. Jacobsen, O. Blacque, H. Berke, E. Herdtweck, Eur. J. Inorg. Chem. (2003) 2463.

[19] J. Cano, M. Sudupe, P. Royo, M.E.G. Mosquera, Angew. Chem., Int. Ed. 45 (2006) 7572.

[20] P. Jutzi, Chem. Rev. 86 (1986) 983.

[21] W.A. Nugent, B.L. Haymore, Coord. Chem. Rev. 31 (1980) 123.

[22] D.E. WigleyProgress in Inorganic Chemistry, vol. 42, Wiley, New York, 1994, p. 239.

[23] M.J. Humphries, M.L.H. Green, M.A. Leech, V.C. Gibson, M. Jolly, D.N. Williams, M.R.J. Elsegood, W. Clegg, J. Chem. Soc., Dalton Trans. (2000) 4044.

[24] M. Sudupe, J. Cano, P. Royo, E. Herdtweck, Eur. J. Inorg. Chem. (2004) 3074.

[25] J. Cano, M. Sudupe, P. Royo, M.E.G. Mosquera, Organometallics 24 (2005) 2424.

[26] D.W. Carpenetti, L. Kloppenburg, J.T. Kupec, J.L. Petersen, Organometallics 15 (1996) 1572.

[27] E. Gielens, J.Y. Tiesnitsch, B. Hessen, J.H. Teuben, Organometallics 17 (1998) 1652.

[28] F. Amor, J. Sánchez-Nieves, P. Royo, H. Jacobsen, O. Blacque, H. Berke, M. Lanfranchi, M.A. Pellinghelli, A. Tiripicchio, Eur. J. Inorg. Chem. (2002) 2810.

[29] F. Amor, A. Butt, K.E. du Plooy, T.P. Spaniol, J. Okuda, Organometallics 17 (1998) 5836.

[30] L. Kloppenburg, J.L. Petersen, Organometallics 16 (1997) 3548.

[31] F. Amor, P. Gómez-Sal, P. Royo, J. Okuda, Organometallics 19 (2000) 5168.

[32] J. Scholz, G.A. Hadi, K.H. Thiele, H. Gorls, R. Weimann, H. Schumann, J. Sieler, J. Organomet. Chem. 626 (2001) 243.

[33] G.J. Pindado, M. Thornton-Pett, M. Bochmann, J. Chem. Soc., Dalton Trans. (1998) 393.

[34] K. Shelly, D.C. Finster, Y.J. Lee, W.R. Scheidt, C.A. Reed, J. Am. Chem. Soc. 107 (1985) 5955.

[35] M. Laguna, M.D. Villacampa, M. Contel, J. Garrido, Inorg. Chem. 37 (1998) 133.

[36] A.S. Batsanov, S.P. Crabtree, J.A.K. Howard, C.W. Lehmann, M. Kilner, J. Organomet. Chem. 550 (1998) 59.

[37] P. Royo Gracia, J. Cano Sierra, M.A. Flores De Paco, B. Pena Garcia, REPSOL QUIMICA SA, EP1225179-B1, p. 1225179.

[38] E.Y.X. Chen, T.J. Marks, Chem. Rev. 100 (2000) 1391.

[39] G. Erker, Dalton Trans. (2005) 1883.

[40] X.M. Yang, C.L. Stern, T.J. Marks, J. Am. Chem. Soc. 116 (1994) 10015.

[41] T. Wondimagegn, Z.T. Xu, K. Vanka, T. Ziegler, Organometallics 23 (2004) 3847.

[42] T.J. Woodman, M. Thornton-Pett, M. Bochmann, Chem. Commun. (2001) 329

[43] V. Amo, R. Andrés, E. de Jesús, F.J. de la Mata, J.C. Flores, R. Gómez, M.P. Gómez-Sal, J.F.C. Turner, Organometallics 24 (2005) 2331. 
[44] R. Gómez, P. Gómez-Sal, P.A. del Real, P. Royo, J. Organomet. Chem. 588 (1999) 22.

[45] V. Tabernero, C. Maestre, G. Jiménez, T. Cuenca, C.R. de Arellano, Organometallics 25 (2006) 1723

[46] K. Phomphrai, A.E. Fenwick, S. Sharma, P.E. Fanwick, J.M. Caruthers, W.N. Delgass, M.M. Abu-Omar, I.P. Rothwell, Organometallics 25 (2006) 214.

[47] T. Wondimagegn, K. Vanka, Z.T. Xu, T. Ziegler, Organometallics 23 (2004) 2651.

[48] T. Wondimagegn, Z.T. Xu, K. Vanka, T. Ziegler, Organometallics 24 (2005) 2076.
[49] H. Hatop, H.W. Roesky, T. Labahn, A. Fischer, H.G. Schmidt, M. Noltemeyer, Organometallics 19 (2000) 937.

[50] S. Dagorne, I.A. Guzei, M.P. Coles, R.F. Jordan, J. Am. Chem. Soc. $122(2000) 274$

[51] S. Döring, G. Erker, R. Fröhlich, O. Meyer, K. Bergander, Organometallics 17 (1998) 2183.

[52] G.C. Welch, R.R.S. Juan, J.D. Masuda, D.W. Stephan, Science 314 (2006) 1124.

[53] P. Arndt, U. Jäger-Fiedler, M. Klahn, W. Baumann, A. Spannenberg, V.V. Burlakov, U. Rosenthal, Angew. Chem., Int. Ed. 45 (2006) 4195. 